\title{
Laboratory investigations of diclofenac migration in saturated porous media - a case study
}

\author{
Monika Okońska $^{1 *}$, Marek Marciniak ${ }^{1}$, Joanna Zembrzuska ${ }^{2}$, \\ Mariusz Kaczmarek ${ }^{3}$ \\ ${ }^{1}$ Adam Mickiewicz University, Institute of Physical Geography and Environmental Planning, Krygowskiego 10, \\ 61-680 Poznań, Poland \\ ${ }^{2}$ Poznan University of Technology, Institute of Chemistry and Technical Electrochemistry, Berdychowo 4, \\ 60-965 Poznań, Poland \\ ${ }^{3}$ Kazimierz Wielki University in Bydgoszcz, Institute of Mechanical Engineering of the Environment and \\ Applied Information Technology, Kopernika 1, 85-074 Bydgoszcz, Poland \\ ${ }^{*}$ corresponding author, e-mail: okonska@amu.edu.pl
}

\begin{abstract}
At present, concentrations of pharmaceuticals in surface and ground waters are low; however, even low concentrations of certain substances may prove very harmful. One of such pharmaceutical drugs is diclofenac, a popular non-steroidal anti-inflammatory drug (NSAID). For this reason, it is important to determine its mobility in groundwater and to estimate parameters of migration. Authors conducted column tests for two porous media: an artificial one, consisting of glass granules, and a natural one, i.e., sandur sand obtained from a site north of the city of Poznan (Poland). During the test, impulse breakthrough curves of chloride ions and diclofenac were recorded. The results were used to identify a specific sorption model and to determine values of migration parameters. Solutions of the inverse problem using optimisation methods and of equations of mathematical migration models were carried out in a MATLAB environment. Based on test results, the mobility of diclofenac is shown to be very high and comparable to that of chloride ions. The tests also revealed a slight and irreversible sorption of diclofenac on grains of both porous media.
\end{abstract}

Key words: non-steroidal anti-inflammatory drug, column test, parameter estimation, optimisation method, MATLAB

\section{Introduction}

Concomitant with advances in civilisation, pharmaceutical drugs have become widely accessible and commonly used. Antibiotics, analgesic and hormonal drugs are employed not only in human health care, but also in veterinary practice. As a result, in household and hospital sewage, agricultural sewage or in post-production waste of pharmaceutical industries, pharmaceutical products in unprocessed form as well as transformation products, the socalled metabolites, may be found (Lahti \& Oikari,
2011; Zembrzuska et al., 2016). During sewage treatment only a portion of pharmaceutical pollutants is permanently removed. At present, under binding legal regulations in Poland, it is not obligatory to monitor and reduce concentrations of pharmaceuticals in post-production sewage or treated sewage that is released into the environment from sewage treatment plants. Similarly, there are no regulations for determining the permissible concentrations of pharmaceutical pollutants in drinking water.

In the literature, reports on measurable concentrations of drugs in surface and ground waters 
(Kasprzyk-Hordern et al., 2008; Kuczyńska, 2017) and even in drinking water (Zwiener, 2007; Valcarcel et al., 2011; Caban et al., 2015) can be found. Although the concentration of pharmaceuticals in water is merely in the range of $\mathrm{ng} / \mathrm{dm}^{3}$ in groundwater and $\mu \mathrm{g} / \mathrm{dm}^{3}$ in surface water, the World Health Organisation has urged institutions worldwide to monitor the occurrence of pharmaceuticals in the aquatic environment, in view of their potential long-term impact on human health (WHO, 2012). At the same time, the European Commission has released a list of substances the circulation of which in the environment is to be monitored and the impact of which on the environment is to be evaluated (EU, 2011, 2013). In the United States, an environmental evaluation is required if the drug's concentration in water exceeds $1 \mu \mathrm{g} / \mathrm{dm}^{3}$ (Santos et al., 2010). The drugs which have not degraded entirely or have not been treated completely can be unknowingly consumed by humans. It should also be noted that in drinking water substances of various medication groups have been found. Such "medication mixtures" can trigger more strongly adverse drug reactions, as a result of their reciprocal interaction, than in the case of a single substance. This may lead to serious health issues (Rizzo et al., 2015).

Therefore, it is of prime importance to recognise the migration of drugs in groundwater, including the processes that may delay their migration towards groundwater intakes. We did research into recognising the migration of selected pharmaceuticals in aquifers and identifying parameter values of their transport and sorption. The present paper discusses results of a test with diclofenac, a popular anti-inflammatory, analgesic and anti-pyretic drug belonging to the group of the non-steroidal anti-inflammatory drugs (NSAIDs) (ECHA, 2018). The application of this pharmaceutical must be carefully overseen, because in the long run overdoses may lead to such health issues as liver impairment, kidney deficiency or even impairment of organs that produce blood components (Dux et al., 1983; Knight et al., 2009). Diclofenac must not be taken by women in the third trimester of pregnancy, nor by patients with circulatory system problems and heart disease (Soubrier et al., 2013; Arfe et al., 2016). Moreover, diclofenac is toxic to aquatic organisms and poses a serious threat to the aquatic environment (Santos et al., 2010; Szymonik\& Lach, 2012; Li, 2014; Acuna et al., 2015).

The rates of effectiveness of removing diclofenac from sewage by means of conventional methods and technology differ and range between 30 and 70 per cent (Zając et al., 2015; Lonappan et al., 2016). The removal of diclofenac from sewage is more ef- fective at those sewage treatment plants that apply biological treatment methods, i.e., that of activated sludge process, which uses micro-organisms. This reduces diclofenac by means of the process of biodegradation rather than through adsorption on the surface of the sludge and its biodegradation is not complete (Larsson et al., 2013; Zając, 2017). Diclofenac is one of the NSAID drugs which is least susceptible to biological decomposition processes (Drozdek et al., 2018). However, Groning et al. (2007) reported on rapid microbiological degradation of diclofenac through biofilms of fluvial sediment under oxic conditions. According to results published in the literature, a potentially effective method of removing diclofenac from water is the photodegradation process which occurs in ultraviolet radiation or in direct sunlight in the presence of semiconductors, typically metallic oxides (Czech, 2012; Bohdziewicz et al., 2014; Kudlek et al., 2016). According to Serrano et al. (2001) diclofenac can be adsorbed in the membrane bioreactor with the addition of powder-activated carbon, which leads to a reduction in the drug's concentration by 85 per cent. The adsorption of diclofenac on soil minerals is classified as low; the pharmaceutical fails to be adsorbed permanently and can be leached from soils (Lin \& Gan, 2011, Caracciolo et al., 2015). Researchers who conducted column tests aimed at recognising the transport behaviour and sorption processes of diclofenac include Mersmann et al. (2002), Scheytt et al. (2004) and Siemens et al. (2010). However, the number of studies on diclofenac sorption in various deposits appears to be still insufficient. In comparison to the limited number of models recorded in the literature, we considered a larger number of sorption models for the present paper.

\section{Material and methods}

\subsection{Laboratory experiments}

In the first stage of the experiments, we conducted a laboratory test in order to determine 1) whether diclofenac photodegrades in sunlight and 2) whether it can adsorb on the walls of the container used for keeping samples of the solution. Two sets of samples were prepared, signed with the letters " $S$ " (sorption) and "SF" (sorption and photodegradation), as well as a zero sample. To prepare the solution, $5.10 \mathrm{mg}$ of diclofenac was dissolved in $1 \mathrm{dm}^{3}$ of distilled water. After the solution was poured into containers, the zero sample was frozen and locked away from the light. The other samples were 
put in a room with partially covered windows at a temperature of $c .20^{\circ} \mathrm{C}$. Samples marked "S" were placed in a container that was cut off from direct sunlight, while samples marked "SF" were left uncovered. Without the access of light, samples in each series were frozen after $1 \mathrm{~h}, 3 \mathrm{~h}, 6 \mathrm{~h}$ and 12 hours following the start of the test. The final " $\mathrm{S}$ " sample was frozen after 24 hours; freezing halts the sorption process.

The diclofenac migration test through porous media was conducted in a plexi filtration column of $9 \mathrm{~cm}$ in diameter and a length of $50 \mathrm{~cm}$. In the test, the solution used was distilled water that contained chloride ions $(\mathrm{Cl})$ and diclofenac (DIC). The column was filled with ball-shaped glass granules of 300$400 \mu \mathrm{m}$ in diameter $\left(d_{10}=0.28 \mathrm{~mm}\right)$ and a uniformity coefficient $C_{U}=1.25$. The other test looked into the migration of chloride ions and diclofenac in natural sediment, i.e., a sample of sandur sand obtained from a site north of the city of Poznań. This was a medium-grained quartz sand $\left(d_{10}=0.28 \mathrm{~mm}\right)$, with a total organic carbon (TOC) of 0.047 per cent and a trace amount of clay fraction. The sand sample contained clay minerals such as smectite, illite and kaolinite. The sand uniformity coefficient $C_{U}$ was 1.83 .

The flow through the filtration column was induced by constant hydraulic gradient $i$. In the tests, flow rate $Q$ was measured, which made it possible to determine the value of hydraulic conductivity $k$. The total porosity $n$ was calculated by the weight method, based on measuring the weight of a dry sample of porous material $m$, its volume $V$ and knowledge of the density of the matrix material $\rho_{s}$ (Myślińska, 1998). At first the effective porosity $n_{e}$ was calculated for connected pores by means of the volumetric method, measuring the volume of porous material $V$ and the volume of water used to saturate the porous medium $V_{w}$. In the next step, the effective porosity $n_{e}$ was finally determined as the ratio of average filtration velocity $v_{a}$ to effective velocity $v$ calculated on the basis of average transport time of the chloride ions in the column (Kleczkowski, 1984; Małecki et al., 2006). The solution injection took the form of a short-term pulse (Okońska, 2006). The tests were conducted in a darkened laboratory room. The samples of input and outflow solutions were placed in plastic containers, the chemical indifference of which was verified at the start of the laboratory work. Such plastic containers are more convenient for transporting samples and, unlike glass containers, they do not break during freezing and thawing processes (Wilga, 2008). Samples of the solution were kept frozen and away from light until they were analysed to determine the concentration of diclofenac and chloride ions.
Determination of diclofenac was performed with a chromatographic system UltiMate 3000 RSLC (Dionex, Thermo, USA), coupled to an API 4000 QTRAP triple quadrupole mass spectrometer with electrospray ionisation (ESI) (from AB Sciex, Foster City, CA, USA) in negative ionisation mode (UHPLC-ESI MS/MS). A Hypersil Gold C18 RP $(100 \mathrm{~mm} \times 2.1 \mathrm{~mm}, 1.9 \mu \mathrm{m}$ particle size) column from Thermo Scientific, USA, was used for chromatographic separation of compound. The temperature in the column of the chromatographic system was maintained at $35^{\circ} \mathrm{C}$ and the injection volume was $5.0 \mu \mathrm{L}$. For UHPLC-ESI MS/MS analysis the mobile phase was a gradient prepared from Milli-Q water containing $5 \mathrm{mmol} / \mathrm{dm}^{3}$ ammonium acetate (component A) and $\mathrm{MeOH}$ (component B). The following gradient was used: 0 min 30 per cent $B, 10$ min 67 per cent $B, 11$ min 100 per cent $B$ and held for $1 \mathrm{~min}$; the flow rate was $0.2 \mathrm{~mL} / \mathrm{min}$. A post run time was set at $5.0 \mathrm{~min}$ for column equilibration before the next injection. The operating conditions for mass spectrometry for diclofenac were as follows: curtain gas 20 psi, nebuliser gas and auxiliary gas 40 psi, source temperature $400^{\circ} \mathrm{C}$, ion spray voltage $-4,500 \mathrm{~V}$ and collision gas set to medium. Quantitative analysis of the compounds was performed in multiple reaction monitoring (MRM) mode. For the analysis one transition of the deprotonated molecular ion and their respective ion product was chosen. These transitions $(\mathrm{m} / \mathrm{z})$ with associated declustering potentials $(\mathrm{V})$ and collision energies $(\mathrm{V})$ were: $294 \rightarrow 250,-40,-18$; and $294 \rightarrow 214,-40,-30$.

Due to the presence of organic compounds in the water samples, the concentration of chloride ions was marked by means of the argentometric titration method. In the test, a burette of increased accuracy was used. However, due to the limited volume of the solution sample analysed, the measurement accuracy was $2.5 \mathrm{mg} \mathrm{Cl}^{-} / \mathrm{dm}^{3}$.

\subsection{Mathematical models}

The mathematical description of the transport and sorption of substances in porous media considered by us (Okońska et al., 2017) refers to twelve different models, all of which are symbolically represented in Table 1.

The transport of inert chloride ions was described with a one-dimensional advection-dispersion equation (A-D model):

$$
\frac{\partial C}{\partial t}=-v \frac{\partial C}{\partial x}+\left(D_{e}+D_{x}\right) \frac{\partial^{2} C}{\partial x^{2}}
$$


Table 1. An overview of mathematical models under consideration

\begin{tabular}{ccccc}
\hline Advection-dispersion model & \multicolumn{4}{c}{ Sorption model } \\
\hline \multirow{3}{*}{ A-D } & & H & F & L \\
& I & H-I & F-I & L-I \\
& R & H-R & F-R & L-R \\
\hline
\end{tabular}

H - Henry model, F - Freundlich model, L - Langmuir model, I - irreversible sorption model, $\mathrm{R}$ - reversible sorption model, H-I - Henry with irreversible sorption model, F-I - Freundlich with irreversible sorption model, L-I - Langmuir with irreversible sorption model, H-R - Henry with reversible sorption model, F-R - Freundlich with reversible sorption model, L-R - Langmuir with reversible sorption model.

where $C$ is the flux-averaged concentration of the substance in the liquid phase $\left[\mathrm{M} / \mathrm{L}^{3}\right]$ (Kreft \& Zuber, 1978; Parker \& van Genuchten, 1984), $t$ is time [T], $x$ is distance $[\mathrm{L}], v$ is effective water velocity $[\mathrm{L} / \mathrm{T}], D$ is the effective diffusion coefficient $\left[\mathrm{L}^{2} / \mathrm{T}\right]$ and $D_{x}$ is the longitudinal dispersivity coefficient $\left[\mathrm{L}^{2} / \mathrm{T}\right]$. The velocity $v$ was defined as $v=\frac{k i}{n_{e}}$, where $k$ is the hydraulic conductivity $[\mathrm{L} / \mathrm{T}], i$ is the hydraulic gradient $[\mathrm{L} / \mathrm{L}]$ and $n_{e}$ is the effective porosity [-]. The dispersivity coefficient $D_{x}$ was defined as $D_{x}=\alpha v$, where $\alpha$ is the longitudinal dispersivity [L]. According to the calculated Peclet number, the influence of molecular diffusion on the substance's migration through the porous media can be neglected. Therefore, the coefficient $D_{e}$ equal to $0 \mathrm{~m}^{2} / \mathrm{s}$ in the mathematical model was assumed.

The migration of diclofenac was described with the following equation:

$$
\frac{\partial C}{\partial t}=-v \frac{\partial C}{\partial x}+D_{x} \frac{\partial^{2} C}{\partial x^{2}}-\frac{\rho_{d}}{n_{e}} \frac{\partial s}{\partial t}
$$

where $\rho_{d}$ is the bulk density of the porous medium $\left[\mathrm{M} / \mathrm{L}^{3}\right]$ and the variable $s$, describing equilibrium sorption $s_{e}$ and non-equilibrium sorption $s_{n^{\prime}}$ can be substituted with an equation $s=s_{e}+s_{n}$.

The relative recovery of chloride ions and diclofenac was calculated with the Descriptors2.m code (Okońska \& Pietrewicz, 2018; Okońska et al., 2019). Next, on the basis of the mathematical model selection algorithm (Fig. 1), out of the eleven sorption models under examination, the following three models, which can be used to describe diclofenac sorption in the porous medium, were selected:

1. The irreversible kinetic sorption model (I model)

$$
s_{e}=0 \text { and } \frac{\partial s_{n}}{\partial t}=k_{1} C
$$

where $k_{1}$ is the irreversible sorption rate coefficient $\left[\mathrm{L}^{3} / \mathrm{MT}\right]$;

2. The Henry model with the irreversible kinetic sorption model (H-I model)

$$
s_{e}=K_{H} C \text { and } \frac{\partial s_{n}}{\partial t}=k_{1} C
$$

where $K_{H}$ is the Henry distribution coefficient $\left[\mathrm{L}^{3} / \mathrm{M}\right]$;

3. The Freundlich model with the irreversible kinetic sorption model (F-I model)

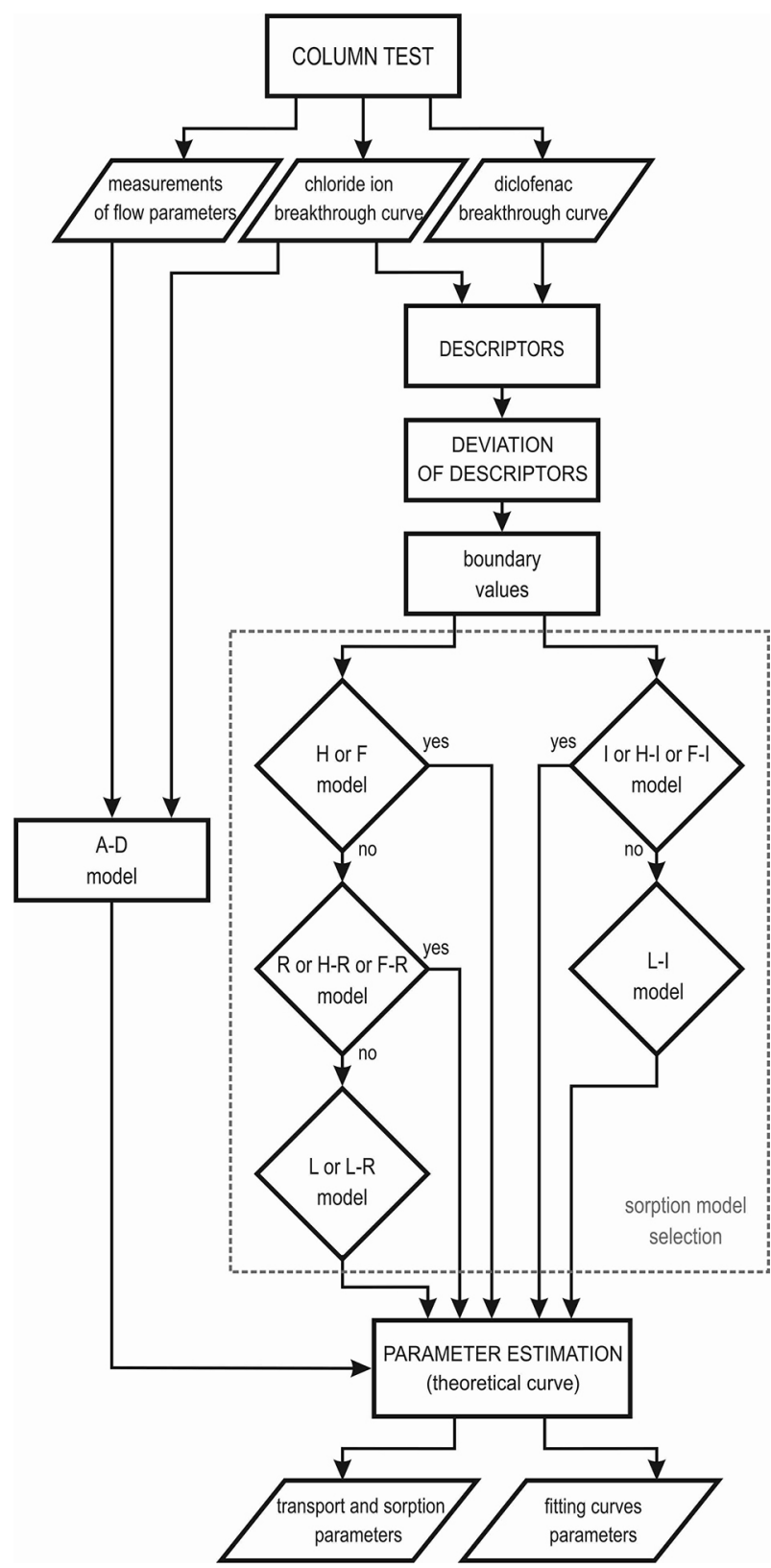

Fig. 1. Algorithm of mathematical model identification and parameter estimation 


$$
s_{e}=K_{F} C^{n} F \text { and } \frac{\partial s_{n}}{\partial t}=k_{1} C
$$

where $K_{F}$ is the Freundlich sorption coefficient $\left[\mathrm{L}^{3} / \mathrm{M}\right]$, and $n_{F}$ is the Freundlich sorption exponent $[-]$.

The results of the column test itself do not make it clear whether the observed mass reduction of diclofenac during its migration through the column is an effect of irreversible sorption or of the degradation process. On the basis of preliminary data, we ruled out the possible impact of photodegradation on the mass balance of diclofenac. At the same time, due to the short duration of the column test, development of micro-organisms was not possible, which in turn ruled out biodegradation. Photocatalysis was not possible, and no additional chemical reagents were introduced to the column, except for the substances examined, which causes that chemical degradation may not be considered. Thus, it can be stated explicitly that the dominant process was irreversible sorption.

In order to solve partial differential equations to describe the migration of substances through the column, column test standard boundary conditions were assumed. For the flow and solution injection at column input, Dirichlet boundary condition was assumed, while at column output Neumann boundary condition was applied (Okońska et al., 2017).

\subsection{Numerical analysis}

Identification of parameters of transport and sorption and numerical solution of the adopted mathematical model were conducted in a MATLAB environment (Okońska et al., 2017). In order to solve the model of transport, which is composed of the partial differential equation with appropriate initial and boundary conditions for pulse-type injection, pdepe function (implemented in MATLAB) was used. The function combines the finite element (for discretization in space) and the finite difference (for time discretization) methods assuming triangular meshing. In order to avoid numerical dispersion, the time intervals between laboratory data were supplemented numerically by additional points using interpolation. The numerical solutions were tested using an analytical benchmark. The identification of transport and sorption parameters was performed with the help of the built-in lsqcurvefit function dedicated to the solution of non-linear optimisation problems assuming least-square fitting.

To that end, a calculation code Id_Test_Kol4.m with the functional interface Id_Test_Kol4.fig were used, which required, in an A-D model, to enter the data from the column test and the initial values of longitudinal dispersivity $\alpha$. At the same time, when determining the value of this parameter, the value of hydraulic conductivity $k$ was further detailed due to the possible measurement error of \pm 10 per cent. In the sorption models, apart from the data obtained from the column test, initial values of sorption parameters were entered, which were estimated over subsequent iterative steps.

Evaluation of the quality of fit of theoretical and experimental breakthrough curves of the migration of chloride ions and diclofenac was done by applying curve parameters: root mean square error (RMSE) and correlation coefficient $r$ (Małecki et al., 2006).

The next stage involved calculation of the value of retardation $R$ on the basis of the value obtained through optimisation of the Henry distribution coefficient $K_{H}$ or the Freundlich sorption coefficient $K_{F}$, respectively (Okońska, 2006; Kret et al., 2015):

$$
\begin{gathered}
R=1+\frac{\rho_{d} K_{H}}{n_{e}} \\
R=1+\frac{\rho_{d} K_{F} n C^{n-1}}{n_{e}}
\end{gathered}
$$

\section{Results and discussion}

\subsection{Laboratory test}

Based on the outcome of the laboratory test, it can be assumed that under the conditions applied, diclofenac is not photodegradable in sunlight and does not adsorb on the walls of the plastic container intended for keeping the solution samples (Fig. 2).

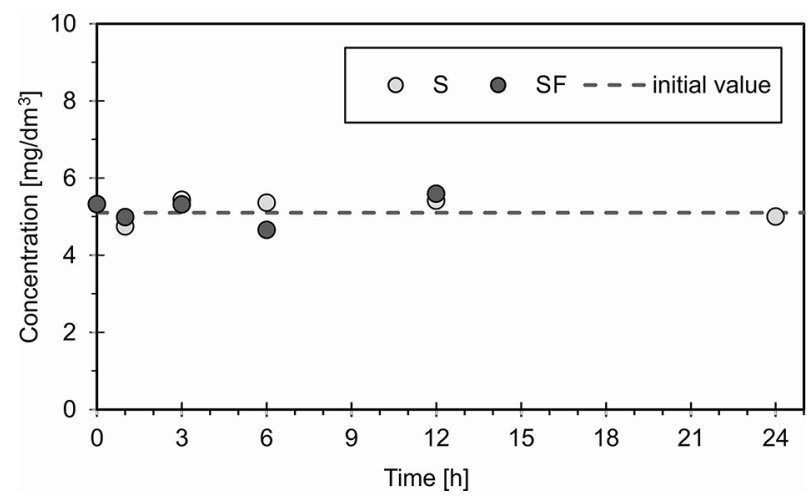

Fig. 2. Concentrations of diclofenac in water samples: S sorption, SF - sorption and photodegradation 
Cases described in the literature show that the process of photodegradation by exposure to sunlight or UV radiation is more intense when catalytic agents and organic substances in soil samples are present. In the porous media under examination, characterised by a lack of or by an inconsiderable content of organic substances, plus limited access of direct sunlight, the scale of decay of the pharmaceutical through the process of photodegradation can be neglected.

\subsection{Experimental breakthrough curves}

Values of flow parameters and injection data recorded during the column tests are presented in Table 2. These data confirm similar conditions of flow and injection in both cases analysed.

The analysis of the normalised breakthrough curves of chloride ions and diclofenac through porous media (Fig. 3) revealed a similar transport behaviour of the substance on both glass granules and sand. Practically, retardation of diclofenac migration compared to chloride ions is not observed, while the mass balance of the pharmaceutical at column input and output indicates a reduction in the drug's mass during its migration through both types of porous media. The calculated recovery of diclofenac is 95 per cent for glass granules and 89 per cent for sand.

\subsection{Migration parameters}

Calculated (with the help of identified parameters) numerical breakthrough curves of chloride ions and diclofenac through glass granules and sand are shown in Figure 4, while the identified values of advection-dispersion and sorption parameters are presented in Table 3.

A good fit of theoretical and experimental breakthrough curves was obtained. As far as the A-D models are concerned, the RMSE was in the range of $0.1-0.2 \mathrm{mg} / \mathrm{dm}^{3}$, and coefficient $r$ in the range 0.993-0.999.

The value of hydraulic conductivity $k$, obtained through the optimisation in a MATLAB environment, of the chloride ions breakthrough curve, is lower than the value measured during the experiment, i.e., by 2.4 per cent for glass granules and by 0.7 per cent for sand, which is comfortably within the measurement error.

The determined values of longitudinal dispersivity $\alpha$ are $0.0015 \mathrm{~m}$ for glass granules and 0.0013 for sand. The values measured in both types of porous media are similar and characteristic of tests on a laboratory scale. They indicate the homogeneity of the porous media under examination. The results obtained are consistent with the assumptions and correspond with uniformity coefficient $C_{U}$.

Table 2. Flow and injection parameters registered during column tests

\begin{tabular}{|c|c|c|c|c|}
\hline Parameter & Symbol & Unit & Glass granules & Sand \\
\hline Sample length & $x$ & $\mathrm{~m}$ & 0.470 & 0.458 \\
\hline Hydraulic gradient & $i$ & - & 0.043 & 0.044 \\
\hline Total porosity & $n$ & - & 0.39 & 0.36 \\
\hline Effective porosity & $n_{e}$ & - & 0.36 & 0.34 \\
\hline Volumetric flow rate & $Q$ & $\mathrm{~cm}^{3} / \mathrm{s}$ & 0.158 & 0.152 \\
\hline Hydraulic conductivity & $k$ & $\mathrm{~m} / \mathrm{s}$ & $5.85 \times 10^{-4}$ & $5.47 \times 10^{-4}$ \\
\hline $\mathrm{Cl} / \mathrm{DIC}$ concentration in the injected solution & $C_{0}$ & $\mathrm{mg} / \mathrm{dm}^{3}$ & $300 / 2.388$ & $300 / 2.398$ \\
\hline Injection time & $t_{\text {in }}$ & $\min$ & 46 & 44 \\
\hline
\end{tabular}
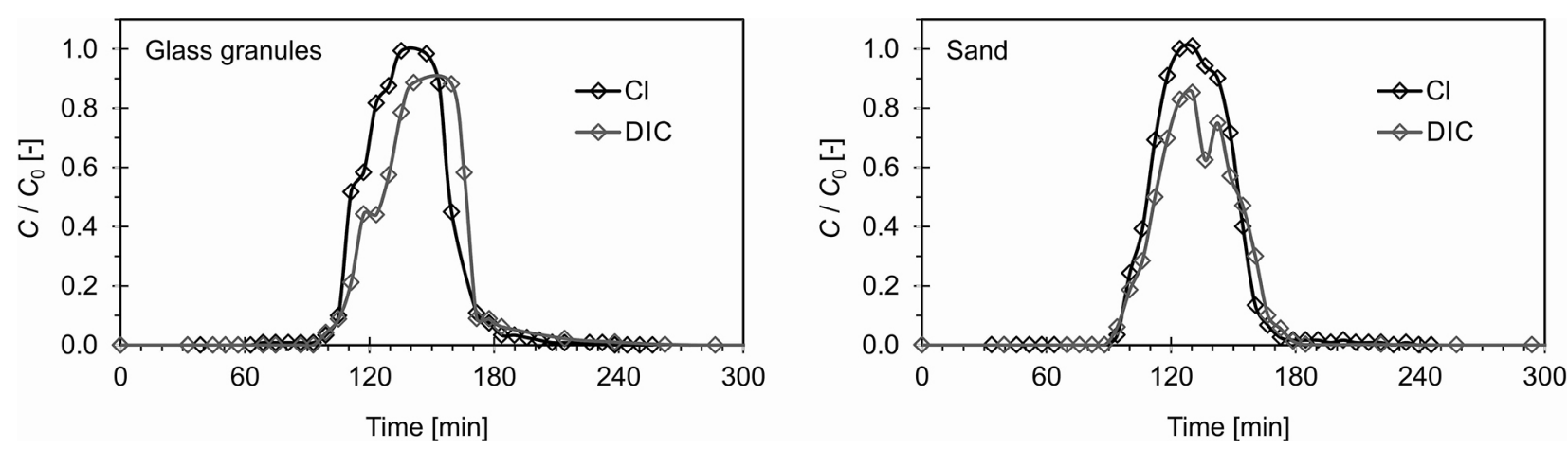

Fig. 3. Experimental breakthrough curves 
The migration of diclofenac in the porous media is best described by the F-I model when it comes to glass granules, and by the H-I model where sand is concerned. Moreover, the above-mentioned sorption models obtained the highest indicator values with regard to the fit of theoretical and experi-
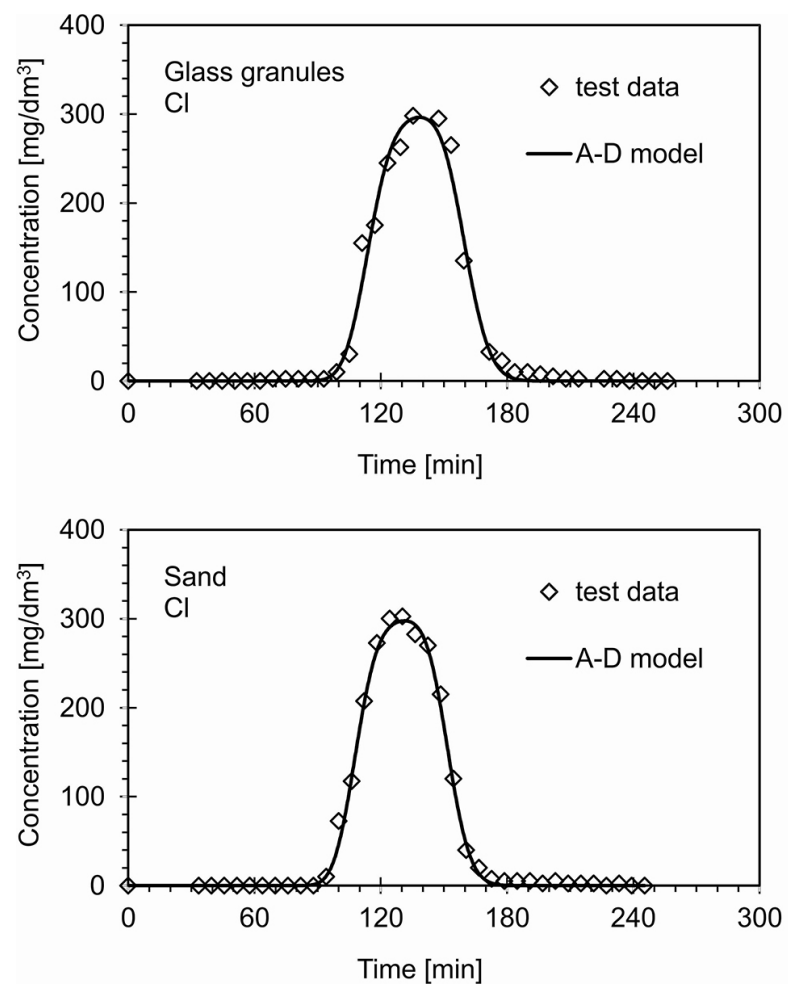

mental breakthrough curves of the pharmaceutical in question $\left(\mathrm{RMSE}=0.016 \mathrm{mg} / \mathrm{dm}^{3}, r=0.988\right.$ and RMSE $=0.021 \mathrm{mg} / \mathrm{dm}^{3}, r=0.987$, respectively). In the optimisation process, sand obtained the $n_{F}=1$ Freundlich exponent in the F-I model, the equation assumed the character of a linear isotherm.
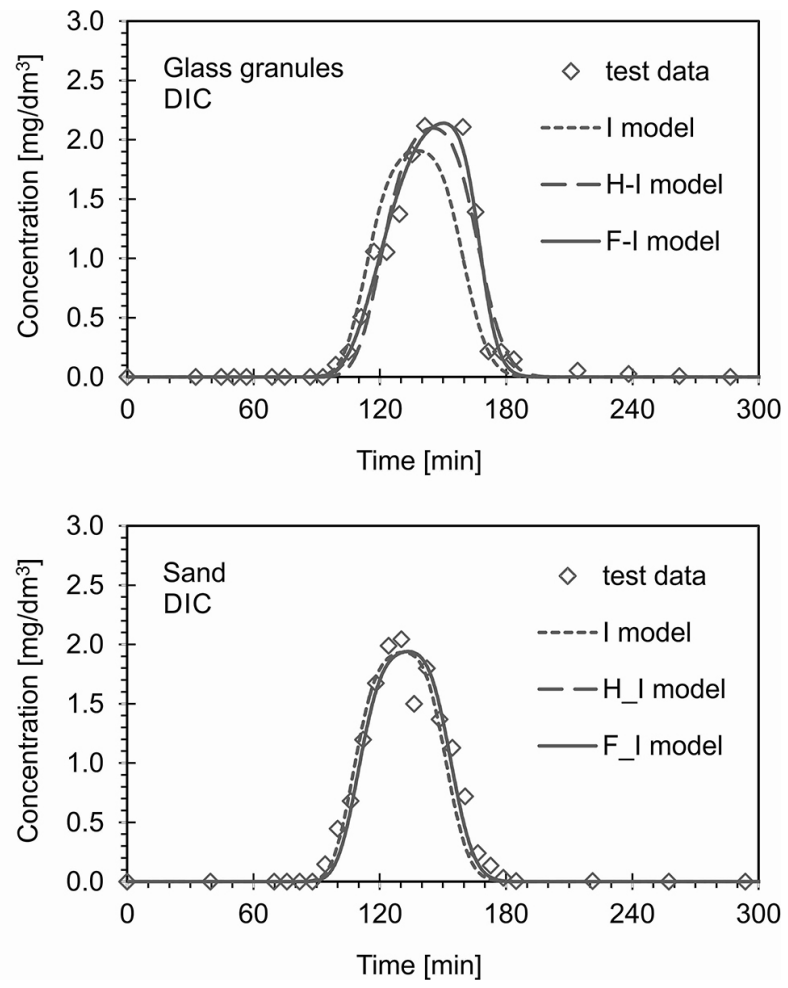

Fig. 4. Theoretical breakthrough curves calculated in MATLAB against experimental points

Table 3. Parameters of transport and sorption calculated in MATLAB

\begin{tabular}{|c|c|c|c|c|}
\hline Parameter & Symbol & Unit & Glass granules & Sand \\
\hline \multicolumn{5}{|c|}{ A-D model } \\
\hline Hydraulic conductivity & $k$ & $\mathrm{~m} / \mathrm{s}$ & $5.71 \times 10^{-4}$ & $5.43 \times 10^{-4}$ \\
\hline Dispersivity & $\alpha$ & $\mathrm{m}$ & 0.0015 & 0.0013 \\
\hline Root mean square error & RMSE & $\mathrm{mg} / \mathrm{dm}^{3}$ & 0.200 & 0.103 \\
\hline Correlation coefficient & $r$ & - & 0.993 & 0.999 \\
\hline \multicolumn{5}{|c|}{ I model } \\
\hline Irreversible sorption rate coefficient & $k_{1}$ & $\mathrm{dm}^{3} / \mathrm{kg} \mathrm{s}$ & $7.09 \times 10^{-6}$ & $6.22 \times 10^{-6}$ \\
\hline Root mean square error & RMSE & $\mathrm{mg} / \mathrm{dm}^{3}$ & 0.044 & 0.025 \\
\hline Correlation coefficient & $r$ & - & 0.907 & 0.980 \\
\hline \multicolumn{5}{|c|}{ H-I model } \\
\hline Henry distribution coefficient & $K_{H}$ & $\mathrm{dm}^{3} / \mathrm{kg}$ & $1.42 \times 10^{-2}$ & $4.15 \times 10^{-3}$ \\
\hline Irreversible sorption rate coefficient & $k_{1}$ & $\mathrm{dm}^{3} / \mathrm{kg} \mathrm{s}$ & $3.70 \times 10^{-6}$ & $6.07 \times 10^{-6}$ \\
\hline Root mean square error & RMSE & $\mathrm{mg} / \mathrm{dm}^{3}$ & 0.024 & 0.021 \\
\hline Correlation coefficient & $r$ & - & 0.973 & 0.987 \\
\hline \multicolumn{5}{|c|}{ F-I model } \\
\hline Freundlicha sorption coefficient & $K_{F}$ & $\mathrm{dm}^{3} / \mathrm{kg}$ & $6.35 \times 10^{-3}$ & $4.15 \times 10^{-3}$ \\
\hline Freundlich sorption exponent & $n_{F}$ & - & 2 & 1 \\
\hline Irreversible sorption rate coefficient & $k_{1}$ & $\mathrm{dm}^{3} / \mathrm{kg} \mathrm{s}$ & $2.86 \times 10^{-6}$ & $6.07 \times 10^{-6}$ \\
\hline Root mean square error & RMSE & $\mathrm{mg} / \mathrm{dm}^{3}$ & 0.016 & 0.021 \\
\hline Correlation coefficient & $r$ & - & 0.988 & 0.987 \\
\hline
\end{tabular}


The value of retardation $R$, calculated on the basis of the Freundlich sorption parameters according of equation (7) for glass granules, is 1.11 , with the diclofenac concentration $C$ equal to $2.116 \mathrm{mg} / \mathrm{dm}^{3}$, and the bulk density of the porous medium $\rho_{d} 1.51$ $\mathrm{g} / \mathrm{cm}^{3}$. The value of retardation $R$, calculated on the basis of the Henry distribution coefficient according to equation (6) for sand, is 1.02 , with the bulk density of the porous medium $\rho_{d} 1.70 \mathrm{~g} / \mathrm{cm}^{3}$. The obtained values of $R$ signify a slight retardation of the migration of the former medium and no retardation of the latter. The findings obtained prove that diclofenac is transported through the samples at roughly the same velocity as chloride ions, but during the process the mass of the pharmaceutical is reduced by 5 to 11 per cent, depending on the media type. We proved that the loss in mass is an effect of irreversible sorption on porous material. The findings of the experiments rule out the possibility of drug degradation through exposure to light or its adsorption on the walls of containers used for water samples.

The findings of the tests correspond with literature data, and also with observations on the migration of pharmaceuticals published by Bertelkamp et al. (2014), who found that the retardation for most of the compounds analysed was close to 1 . Scheytt et al. (2004), in their column tests with medium sand of $\mathrm{TOC}=2.4 \mathrm{~g} / \mathrm{kg}(0.24 \%)$, and a pharmaceutical concentration of $10 \mu \mathrm{g} / \mathrm{dm}^{3}$ in injected groundwater, found that retardation of diclofenac was $R=2.0$, with a recovery figure of 97 per cent. The $R$ was calculated as the ratio of velocity of water and that of the pharmaceutical.

The migration of diclofenac as a single compound could be slightly less intensive as proved by Mersmann et al. (2002), who carried out a test involving only this particular drug, i.e., without addition of any other pharmaceuticals. The retardation obtained by those authors was $R=2.6$, with the diclofenac concentration being $10 \mu \mathrm{g} / \mathrm{dm}^{3}$ in injected water.

The literature offers a way of approximate calculation of the distribution coefficient $K_{H}$ on the basis of predicted distribution coefficient $K_{O C}$ and the content of total organic carbon, TOC\% (Małecki et al., 2006). The value of coefficient $K_{O C}$ for diclofenac can be found in the works of Mersmann et al. (2002) and Scheytt et al. (2004). The distribution coefficient $K_{H}$ for diclofenac migration in sand, calculated by means of the above-mentioned method, was $3.76-5.92 \times 10^{-2} \mathrm{dm}^{3} / \mathrm{kg}$ and turned out to be an order of magnitude higher than the parameter value obtained in the column test with the sand sample analysed.

\section{Conclusions}

The present note discusses findings of a test on the migration of diclofenac through filtration columns filled with two types of porous media: glass granules and sandur sand, with a low content of organic carbon. The test was conducted under oxic conditions, with concentrations of the drug slightly higher than observed in the environment. As the preliminary laboratory test findings revealed that under conditions of the experiment the photodegradation process did not occur, diclofenac sorption was examined on grains. The conditions in the darkened laboratory room, where the column tests were conducted, to a certain degree reflected those of the saturation zone, where the photodegradation process cannot take place due to a lack of sunlight and UV radiation. The limited access of light and short duration of the test ensured that micro-organisms had no time and not enough light to grow and develop. During the experiment photocatalysis was not possible, and no additional chemical reagents were introduced to the column, with the exception of the substances examined. This rules out biological or chemical degradation in the processes under consideration. The test findings revealed that in saturated porous media diclofenac migrates as rapidly as chloride ions. Retardation was close to 1, which indicates diclofenac mobility. In the case of migration, taking into account the sorption in accordance with the Freundlich model, it is possible that the value of retardation $R$ will be higher depending on the concentration of the pharmaceutical in groundwater (Eq. 7).

The findings also showed a small irreversible sorption of diclofenac on glass granules and sand grains, resulting in a mass loss of the drug of 5 to 11 per cent. This means that, taken the low content of organic substances and the absence of micro-organisms in aquifers, water will not be self-purified by means of degradation of the drug. Therefore, the ground water protection system should be aimed at reducing the possibility of diclofenac reaching groundwater, particularly in aquifers that are located near groundwater intake points.

\section{Acknowledgements}

The results presented here were obtained as part of research project no. DEC-2011/01/B/ST10/02063 financed by the National Science Centre (Poland). We wish to express our gratitude to Katarzyna Pietrewicz for help in carrying out laboratory tests and to the reviewers for constructive comments on a previous version of the typescript. 


\section{References}

Acuna, V., Ginebreda, A., Mor, J.R., Petrovic, M., Sabater, S., Sumpter, J. \& Barceló, D., 2015. Balancing the health benefits and environmental risks of pharmaceuticals: Diclofenac as an example. Environment International 85, 327-333.

Arfe, A., Scotti, L., Varas-Lorenzo, C., Nicotra, F., Zambon, A., Kollhorst, B., Schink, T., Garbe, E., Herings, R., Straatman, H., Schade, R., Villa, M., Lucchi, S., Valkhoff, V., Romio, S., Thiessard, F., Schuemie, M., Pariente, A., Sturkenboom, M. \& Corrao, G., 2016. Non-steroidal anti-inflammatory drugs and risk of heart failure in four European countries: nested case-control study. British Medical Journal 354, i4857.

Bertelkamp, C., Reungoat, J., Cornelissen, E.R., Singhal, N., Reynisson, J., Cabo, A.J., van der Hoek, J.P. \& Verliefde, A.R.D., 2014. Sorption and biodegradation of organic micropollutants during river bank filtration: A laboratory column study. Water Research 52, 231241.

Bohdziewicz, J., Kudlek, E. \& Dudziak, M., 2016. Influence of the catalyst type $\left(\mathrm{TiO}_{2}\right.$ and $\left.\mathrm{ZnO}\right)$ on the photocatalytic oxidation of pharmaceuticals in the aquatic environment. Desalination and Water Treatment 57, 1552-1563.

Caban, M., Lis, E., Kumirska, J. \& Stepnowski, P., 2015. Determination of pharmaceutical residues in drinking water in Poland using a new SPE-GC-MS (SIM) method based on Speedisk extraction disks and DIMETRIS derivatization. Science of the Total Environment 538, 402-411.

Caracciolo, A.B., Topp, E. \& Grenni, P., 2015. Pharmaceuticals in the environment: Biodegradation and effects on natural microbial communities. A review. Journal of Pharmaceutical and Biomedical Analysis 106, 25-36.

Czech, B., 2012. Usuwanie farmaceutyków z wód i ścieków z wykorzystaniem metod adsorpcyjnych i fotokatalitycznych [Removal of pharmaceuticals from water and sewage by applying adsorption and photocatalytic methods]. [In:] J. Ryczkowski (Ed.): Adsorbenty $i$ katalizatory - Wybrane technologie a środowisko [Adsorbents and Catalysts - Selected Technologies and the Environment]. Uniwersytet Rzeszowski, Rzeszów, 443-452.

Drozdek, E., Żyłła, R., Gmurek, M., Milala, R. \& Ledakowicz, S., 2018. Usuwanie trudno biodegradowalnych farmaceutyków zintegrowanymi metodami pogłębionego utleniania i filtracji membranowej [Removal of difficult biodegradable pharmaceuticals with integrated methods of advanced oxidation and membrane filtration]. Acta Scientiarum Polonorum Biotechnologia 17, 5-14.

Dux, S., Groslop, I., Garty, M. \& Rosenfeld, J.B., 1983. Anaphylactic shock induced by diclofenac. British Medical Journal 286, 1861.

ECHA, 2018. Diclofenac (EC no. 239-348-5). European Chemicals Agency. [Online] Access: http://echa.europa.eu/, March 5, 2019.

EU, 2011. COM 875: Report from the Commission to the European Parliament and the Council on the outcome of the review of Annex X to Directive 2000/60/EC of the European Parliament and of the Council on priority substances in the field of water policy. [Online] Access: http://ec.europa.eu/environment/water/ water-dangersub/, March 11, 2019.

EU, 2013. Directive 2013/39/EU of the European Parliament and of the Council of 12 August 2013 amending Directives 2000/60/EC and 2008/105/EC as regards priority substances in the field of water policy. Official Journal of the European Union L 226. [Online] Access: http://data.europa.eu/eli/dir/2013/39/oj, March 11, 2019.

Groning, J., Held, C., Garten, C., Claußnitzer, U., Kaschabek, S.R. \& Schlomann, M., 2007. Transformation of diclofenac by the indigenous microflora of river sediments and identification of a major intermediate. Chemosphere 69, 509-516.

Guzik, U., Hupert-Kocurek, K., Mazur, A. \& Wojcieszyńska, D., 2013. Biotransformacja wybranych niesteroidowych leków przeciwzapalnych w środowisku [Biotransformation of non-steroidal anti-inflammatory drugs in environment]. Bromatologia i Chemia Toksykologiczna 46, 105-112.

Li, W.C., 2014. Occurrence, sources, and fate of pharmaceuticals in aquatic environment and soil. Environmental Pollution 187, 193-201.

Lin, K. \& Gan, J., 2011. Sorption and degradation of wastewater-associated non-steroidal anti-inflammatory drugs and antibiotics in soils. Chemosphere 83, 240-246.

Kasprzyk-Hordern, B., Dąbrowska, A., Vieno, N., Kronberg, L. \& Nawrocki, J., 2008. Occurrence of acidic pharmaceuticals in the Warta River in Poland. Chemia Analityczna 53, 289-303.

Kleczkowski, A.S. (Ed.), 1984. Ochrona wód podziemnych [Protection of groundwater]. Wydawnictwa Geologiczne, Warszawa, $328 \mathrm{pp}$.

Knights, K.M., Winner, L.K., Elliot, D.J., Bowalgaha, K. \& Miners, J.O., 2009. Aldosterone glucuronidation by human liver and kidney microsomes and recombinant UDP-glucuronosyltransferases: Inhibition by NSAIDs. British Journal of Clinical Pharmacology 68, 402-412.

Kreft, A. \& Zuber, A., 1978. On the physical meaning of the dispersion equation and its solutions for different initial and boundary conditions. Chemical Engineering Science 33, 1471-1480.

Kret, E., Kiecak, A., Malina, G., Nijenhuis, I. \& Postawa, A., 2015. Identification of TCE and PCE sorption and biodegradation parameters in a sandy aquifer for fate and transport modelling: batch and column studies. Environmental Science and Pollution Research 22, 98779888.

Kuczyńska, A., 2017. Wyniki pilotażowego badania zawartości substancji czynnych farmaceutyków w wodach podziemnych $\mathrm{w}$ próbkach wody pobranych z krajowej sieci monitoringu wód podziemnych [Results of a pilot study on the assessment of pharmaceuticals in groundwater in samples collected from the national groundwater monitoring network]. Przeglad Geologiczny 65, 1096-1103. 
Kudlek, E., Dudziak, M. \& Bohdziewicz, J., 2016. Influence of inorganic ions and organic substances on the degradation of pharmaceutical compound in water matrix. Water 8, 532 .

Lahti, M. \& Oikari, A., 2011. Microbial transformation of pharmaceuticals naproxen, bisoprolol, and diclofenac in aerobic and anaerobic environments. Archives of Environmental Contamination and Toxicology 61, 202-210.

Larsson, E., Rabayah, A. \& Jönsson, J.A., 2013. Sludge removal of nonsteroidal anti-inflammatory drugs during wastewater treatment studied by direct hollow fiber liquid phase microextraction. Journal of Environmental Protection 4, 946-955.

Lonappan, L., Brar, S.K., Das, R.K., Verma, M. \& Surampalli, R.Y., 2016. Diclofenac and its transformation products: Environmental occurrence and toxicity - A review. Environment International 96, 127-138.

Małecki, J.J., Nawalany, M., Witczak, S. \& Gruszczyński, T., 2006. Wyznaczanie parametrów migracji zanieczyszczeń w ośrodku porowatym dla potrzeb badań hydrogeologicznych i ochrony środowiska. Poradnik metodyczny [Determination of pollutant migration parameters in a porous medium for hydrogeological and environmental protection research. Methodological guide]. Uniwersytet Warszawski, Warszawa, 249 pp.

Mersmann, P., Scheytt, T. \& Heberer, T., 2002. Säulenversuche zum Transportverhalten von Arzneimittelwirkstoffen in der wassergesättigten Zone [Column experiments on the transport behavior of pharmaceutically active compounds in the saturated zone]. Acta Hydrochimica et Hydrobiologica 30, 1-10.

Myślińska, E., 1998. Laboratoryjne badania gruntów [Laboratory investigations of soils]. Wydawnictwo Naukowe PWN, Warszawa, 278 pp.

Okońska, M., 2006. Identyfikacja parametrów migracji zanieczyszczeń w porowatym ośrodku hydrogeologicznym metoda modelowania eksperymentu kolumnowego [The identification of pollutants migration parameters in a groundwater porous medium by the method of the column experiment modelling]. Geologos 9, Poznań, 97 pp.

Okońska, M. \& Pietrewicz, K., 2018. Identification of a mathematical model and parameter estimation of erythromycin migration in two different porous media, based on column tests. Geologia Croatica 71, 47-53.

Okońska, M., Kaczmarek, M., Małoszewski, P. \& Marciniak, M., 2017. The verification of the estimation of transport and sorption parameters in the MATLAB environment. A column test. Geology, Geophysics and Environment 43, 213-227.

Okońska, M., Marciniak, M. \& Kaczmarek, M., 2019. The pulse descriptors in sensitivity studies of no sorption and single sorption column transport models. Journal of Porous Media 22, 563-582.

Parker, J.C. \& van Genuchten, M.Th., 1984. Determining transport parameters from laboratory and field tracer experiments. Virginia Agricultural Experiment Station Bulletin 84, 1-97.

Rizzo, L., Fiorentino, A., Grassi, M., Attanasio, D. \& Guida, M., 2015. Advanced treatment of urban wastewater by sand filtration and graphene adsorption for wastewater reuse: Effect on a mixture of pharmaceu- ticals and toxicity. Journal of Environmental Chemical Engineering 3, 122-128.

Santos, L.H.M.L.M., Araújoa, A.N., Fachini, A., Pena, A., Delerue-Matos, C. \& Montenegro, M.C.B.S.M., 2010. Ecotoxicological aspects related to the presence of pharmaceuticals in the aquatic environment. Journal of Hazardous Materials 175, 45-95.

Soubrier, M., Rosenbaum, D., Tatar, Z., Lahayea, C., Dubost, J.-J. \& Mathieu, S., 2013. Vascular effects of nonsteroidal antiinflammatory drugs. Joint Bone Spine 80, 358-362.

Scheytt, T., Mersmann, P., Leidig, M., Pekdeger, A. \& Heberer, T., 2004. Transport of pharmaceutically active compounds in saturated laboratory columns. Ground Water 42, 767-773.

Serrano, D., Suarez, S., Lema, J.M. \& Omil, F., 2001. Removal of persistent pharmaceutical micropollutants from sewage by addition of PAC in a sequential membrane bioreactor. Water Resources 45, 5323-5333.

Szymonik, A. \& Lach, J., 2012. Zagrożenia środowiska wodnego obecnością środków farmaceutycznych [Pharmaceuticals - potential threats to water environment]. Inżynieria i Ochrona Środowiska 15, 249-263.

Siemens, J., Huschek, G., Walshe, G., Siebe, C., Kasteel, R., Wulf, S., Clemens, J. \& Kaupenjohann, M., 2010. Transport of pharmaceuticals in columns of a wastewater-irrigated Mexican clay soil. Journal of Environmental Quality 39, 1201-1210.

Valcarcel, Y., Alonso, S.G., Rodriguez-Gil, J.L., Maroto, R.R., Gil, A. \& Catala, M., 2011. Analysis of the presence of cardiovascular, analgesic, anti-inflammatory, antipyretic pharmaceuticals in river and drinking water of the Madrid Region of Spain. Chemosphere 82, 1062-1071.

WHO (World Health Organization), 2012. Pharmaceuticals in drinking-water. [Online] Access: http:// www.who.int/water_sanitation_health/publications/2012/pharmaceuticals/en, March 2, 2018.

Wilga, J., 2008. Opracowanie metodyk oznaczania zawartości substancji farmaceutycznych w próbkach środowiskowych [Development of analytical methods for determining pharmaceutical substances in the environmental samples]. Politechnika Gdańska, Gdańsk, 121 pp. [Online] Access: http:/ / pbc.gda.pl/Content/3850/phd_wilga.pdf, March 12, 2019.

Zając, A., 2017. Skuteczność usuwania wybranych niesteroidowych leków przeciwzapalnych ze ścieków metoda osadu czynnego [Efficiency of removing selected non-steroidal anti-inflammatory drugs from wastewater by activated sludge]. Politechnika Poznańska, Poznań, 189 pp.

Zając, A., Zembrzuska, J., Kruszelnicka, I. \& Ginter-Kramarczyk, D., 2015. Sposoby usuwania produktów farmaceutycznych i ich metabolitów z wody i ścieków [Methods for removing pharmaceuticals and their metabolites from water and wastewater]. Przemyst Chemiczny 94, 76-80.

Zembrzuska, J., Ginter-Kramarczyk, D., Kruszelnicka, I. \& Zając, A., 2016. Występowanie niesteroidowych leków przeciwbólowych w Wielkopolsce w ściekach komunalnych i przemysłowych i ich ekotoksykologiczna ocena ryzyka [Occurrence of non-steroidal 
antiinflammatory drugs in municipal wastewater and industrial wastewater of Wielkopolska and their ecotoxicological assessment]. [In:] Z. Dymaczewski, J. Jeż-Walkowiak \& A. Urbaniak (Eds): Zaopatrzenie $w$ wodę, jakość $i$ ochrona wód [Water supply and water quality]. Polskie Zrzeszenie Inżynierów i Techników Sanitarnych, Poznań, 979-994.
Zwiener, C., 2007. Occurrence and analysis of pharmaceuticals and their transformation products in drinking water treatment. Analytical and Bioanalytical Chemistry 387, 1159-1162.

Manuscript received: 1 April 2019 Revision accepted: 22 July 2019 